\title{
Cation exchange: a new strategy for mineral carbonation of smectite-rich kimberlites
}

\author{
N. ZEYEN ${ }^{1}$, B. WANG ${ }^{1}$, S.A. WILSON ${ }^{1}$, K. VON \\ GunTEN $^{1}$, D.S. Alessi ${ }^{1}$, C. PAUlO ${ }^{2}$, A.R. STUBbS ${ }^{2}$, I.M. \\ POWER $^{2}$ \\ ${ }^{1}$ Department of Earth and Atmospheric Sciences, University \\ of Alberta, Edmonton, Canada \\ ${ }^{2}$ Trent School of the Environment, Trent University, \\ Peterborough, Canada
}

Mineral carbonation is a form of carbon capture, utilization and storage (CCUS) that aims to transform excess $\mathrm{CO}_{2}$ into environmentally benign carbonate minerals which are geologically stable. Here, we investigated the reactivity of processed kimberlite and kimberlite ore from the Venetia Diamond Mine (South Africa). Highly reactive phases, such as brucite $\left[\mathrm{Mg}(\mathrm{OH})_{2}\right]$, are uncommon in the samples collected from Venetia necessitating the development of new strategies for mineral carbonation. Kimberlite ore and tailings from this mine consist of a clay-rich mineral assemblage that is dominated by lizardite (a serpentine mineral) and smectites. Smectites are swelling clays that can act as a source of $\mathrm{Mg}$ and $\mathrm{Ca}$ for carbonation reactions via cation exchange, dissolution and/or direct replacement of smectites to form carbonate phases. Although carbonation of serpentine and brucite has long been a focus of CCUS in mine wastes [1], smectite carbonation has not been explored in this setting.

Quantitative X-ray diffraction using Rietveld refinements coupled with Fourier-transform infrared spectroscopy indicate that smectites of stevensite-saponite composition are abundant in the Venetia samples (1.3-15.4 wt.\%). Synchrotron-based X-ray fluorescence mapping correlated with scanning and transmission electron microscopy show that smectites are distributed as altered, smooth regions measuring from 1 to $20 \mu \mathrm{m}$ in breadth. These phases are rich in $\mathrm{Mg}$ and $\mathrm{Ca}$ and Al-poor. To better understand the behaviour/reactivity of smectites during the cation exchange process, we have used batch experiments with pure endmembers of $\mathrm{Ca}-, \mathrm{Mg}$ - and Na-montmorillonite under different treatment conditions $\left(\mathrm{NH}_{4}\right.$-citrate, $\mathrm{NH}_{4}-\mathrm{O}$-acetate, $\mathrm{NH}_{4}-\mathrm{Cl}$ and $\mathrm{Na}_{3}$-citrate). After 24 hours of reaction, ICP-MS analyses reveal that the four treatments have the same efficiency for $\mathrm{Ca}$ and $\mathrm{Mg}$ exchange, while $\mathrm{NH}_{4}-\mathrm{Cl}$ and $\mathrm{NH}_{4}-$ $\mathrm{O}$-acetate treatments minimize calcite dissolution. Our end goals are to optimize settling time and to maximize extraction of $\mathrm{Ca}$ and $\mathrm{Mg}$ for carbonation reactions during ore processing.

[1] Wilson et al., 2009, Economic Geology 104, 95-112 